Check for updates

Cite this: RSC Adv., 2019, 9, 10420

Received 27th March 2019

Accepted 27th March 2019

DOI: 10.1039/c9ra02321f

rsc.li/rsc-advances

\section{Total synthesis of pyrano[3,2-e]indole alkaloid fontanesine B by a double cyclization strategy $\dagger$}

\author{
Tomoki Itoh, Yuusuke Chiba, Shunsuke Kawaguchi, Yuki Koitaya, Yuuma Yoneta, \\ Koji Yamada and Takumi Abe (D)*
}

The regioselective synthesis of pyrano[3,2-e]indole alkaloid fontanesine B by two different cyclizations is described. The complete regioselectivity is controlled by the C4 Pictet-Spengler cyclization, in which an iminium ion acts as a transient directing (TDG) group. Furthermore, carbolines were constructed by a new Bischler-Napieralski-type cyclization, in which an unprecedented trichloromethyl carbamate serves as a reactive group.
Fontanesines A (1), B (2), and C (3) were isolated from the stem bark and leaf fractions of Conchocarpus fontanesianus by Queiroz and co-workers in 2016 (Fig. 1). ${ }^{1}$ These compounds have a characteristic pyrano[3,2-e]indole moiety fused with quinazolinone. A crucial challenge in the synthesis of fontanesines is the regioselective formation of the pyrano[3,2-e]indole core. Although the structures were unique and unprecedented, there are no reports on their partial preparation or total synthesis.

The importance of a pyrano[3,2-e]indole framework in medicinal chemistry had encouraged Macor, ${ }^{2}$ Pandit, ${ }^{3}$ May, ${ }^{4}$ and Conforti ${ }^{5}$ to develop efficient methods for the regioselective construction of this framework. The majority of these methods relied on the thermal Claisen rearrangement, ${ }^{2-4}$ and Ptmediated cyclization. ${ }^{5}$ To keep the pyran intact from earlier stage of total synthesis is difficult due to its instability. ${ }^{6}$

In our continuing efforts in the synthesis of indole alkaloids, ${ }^{7}$ we developed a novel strategy for the synthesis of

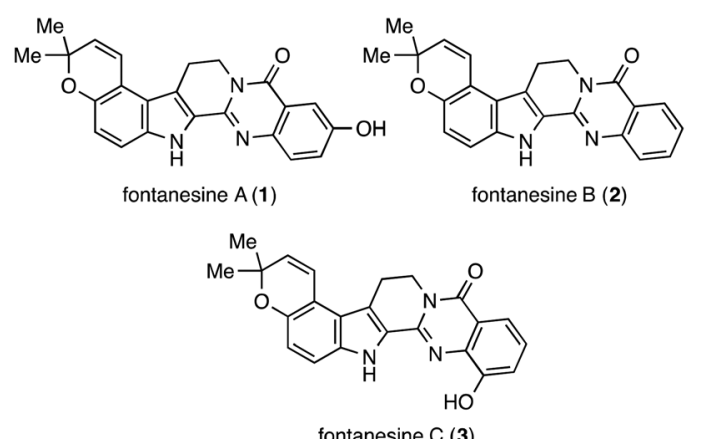

Fig. 1 Fontanesines A (1), B (2), and C (3).

Faculty of Pharmaceutical Sciences, Health Sciences University of Hokkaido, Ishikari-tobetsu, Hokkaido 0610293, Japan. E-mail: abe-t@hoku-iryo-u.ac.jp

$\dagger$ Electronic supplementary information (ESI) available: Detailed experimental procedures and spectra data for all compounds, including scanned images of ${ }^{1} \mathrm{H}$ and ${ }^{13} \mathrm{C}$ NMR spectra. See DOI: $10.1039 / \mathrm{c} 9 \mathrm{ra02321f}$ azepinoindoles by $\mathrm{C} 4$ Pictet-Spengler reaction of serotonins ${ }^{8}$ or 5-hydroxytryptophans ${ }^{9}$ and aldehydes. This approach proved useful in the one-pot regioselective synthesis of pyrano[3,2-e] indoles. ${ }^{10}$ We considered the above facts and envisioned that the synthesis of pyrano[3,2-e]indoles by $\mathrm{C} 4$ Pictet-Spengler reaction would allow a rapid and regioselective formation of fontanesines, keeping the pyran intact. Herein, we report the results of our efforts to synthesize 2 .

The retrosynthetic analysis of fontanesine B (2) is shown in Scheme 1 . The quinazolinone moiety in 2 might be forged by
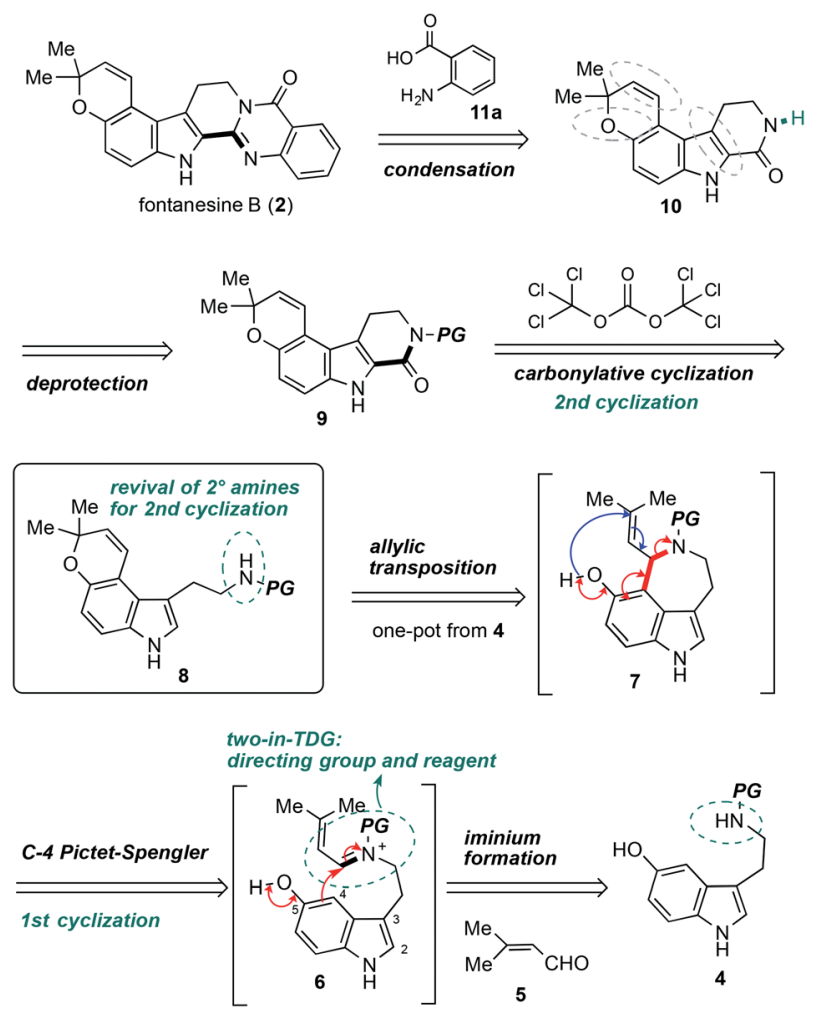

Scheme 1 Retrosynthetic analysis of fontanesine B (2). 


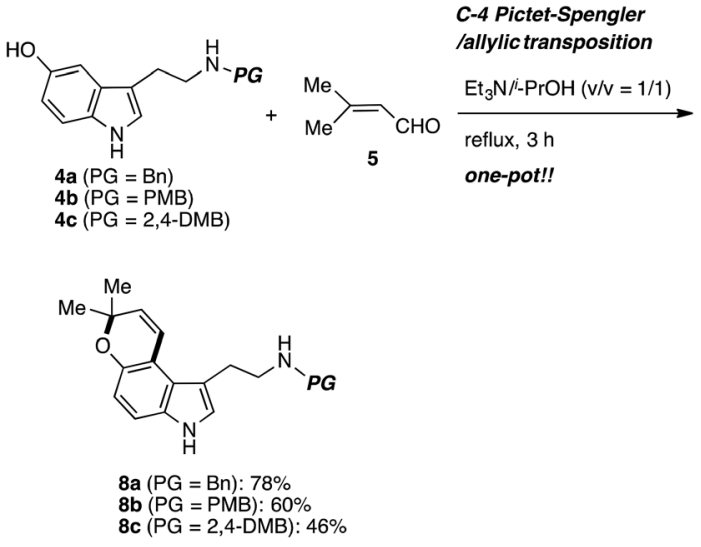

Scheme 2 Synthesis of substrates 8 .
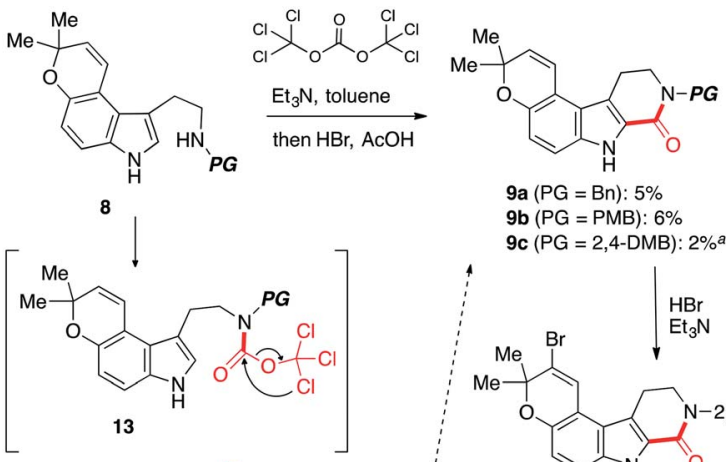

$\longrightarrow \stackrel{c}{<}_{\mathrm{Cl}}$

9a $(P G=B n): 5 \%$ $9 \mathbf{b}(\mathrm{PG}=\mathrm{PMB}): 6 \%$ 9c $(\mathrm{PG}=2,4-\mathrm{DMB}): 2 \%$

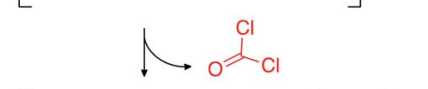<smiles>[AlH][V]</smiles>

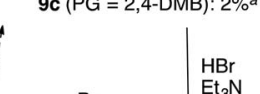<smiles>CC1(C)C=Cc2c(ccc3[nH]cc(CCN(C(=O)O)C(=O)Cl)c23)O1</smiles>

14 $\downarrow \mathrm{Et}_{3} \mathrm{~N}$<smiles>[Y]C(=O)N(CCc1c[nH]c2ccc3c(c12)C=CC([Y6])([Y9])O3)C(=O)[O-]</smiles>

decomposition

Scheme 3 Attempted synthesis of $9 .{ }^{a} 12$ was obtained in $14 \%$ yield.

a deprotection followed by condensation of anthranilic acid (11a) with carboline 9. One of the key steps in the synthetic route involved the carbonylative cyclization of pyrano[3,2-e]indole 8 to afford carboline $\mathbf{9}$. The pyrano[3,2-e]indole 8 could be accessible from aldehyde 5 and benzyl protected 5-hydroxytryptamine 4 using our developed C4 Pictet-Spengler/allylic transposition via the iminium intermediate 6 and azepinoindole 7.

Before synthetic studies, we could predict the difficulty of removing the protecting group on the nitrogen atom at the late stage. Therefore, we decided to prepare the several tryptamines 4 with different protecting groups. The synthesis was started from the benzyl protected 5-hydroxytryptamine 4 (Scheme 2). It was reacted with 3-methyl-2-butenal (5) in 2-propanol/ $\mathrm{Et}_{3} \mathrm{~N}$

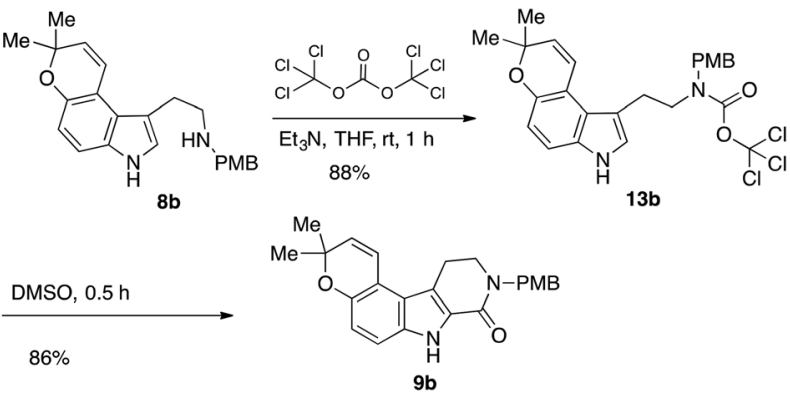

interrupted phosgene cyclization/Bischler-Napieralski-type cyclization sequence

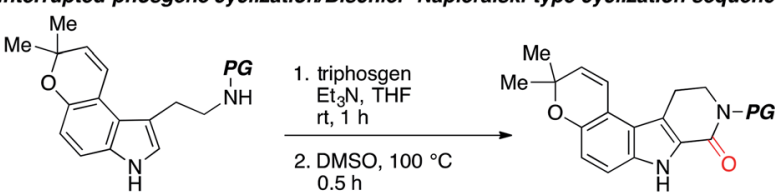

$\mathbf{8} \mathbf{a}(P G=B n)$
$\mathbf{8 b}(P G=P M B)$ $8 \mathbf{c}(P G=2,4-D M B)$

single column chromatography

9a $(\mathrm{PG}=\mathrm{Bn}): 78 \%$ $9 b(P G=P M B): 65 \%$
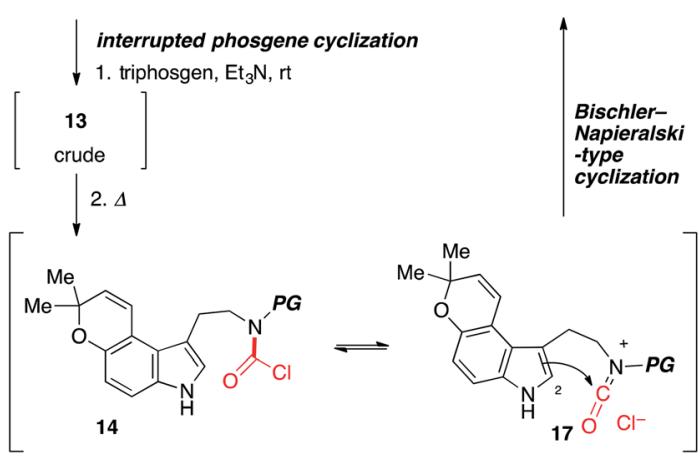

Scheme 4 Improved synthesis of $\beta$-carbolines 9 from 8 via interrupted phosgene cyclization and Bischler-Napieralski-type cyclization.

under reflux to produce the desired pyrano[3,2-e]indole 8 in a one-pot reaction. Normal Pictet-Spengler reaction occurs at the $\mathrm{C} 2$ position of the indole ring under the acidic conditions. All steps of this one-pot sequence take place under basic conditions, which is presumably key to its success.

To test the feasibility of our approach, we resorted to the carbonylative cyclization of 8. According to the previous report on
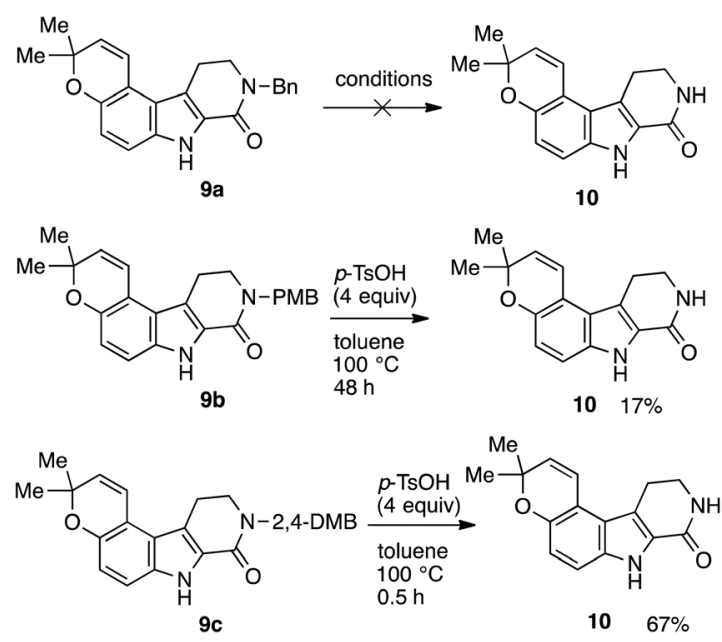

Scheme 5 Removal of benzyl substituents on the nitrogen atoms in 9. 


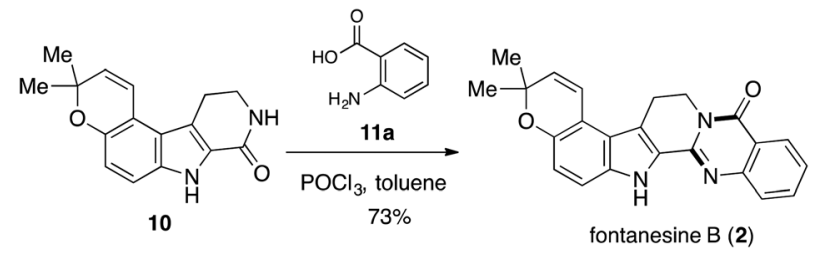

Scheme 6 Completion of total synthesis of fontanesine B. the reaction using triphosgene, ${ }^{\mathbf{1 1 - 1 3}}$ which is a bench-stable solid and easy to handle, ${ }^{\mathbf{1 4}}$ we investigated the conversion of $\mathbf{8}$ into $\mathbf{9}$ through intermediate 13 (ref. 15) (Scheme 3). Numerous attempts including screening of bases to achieve this have resulted in the polymerization and halogenation ${ }^{13}$ of 8 over the carbonylative cyclization. ${ }^{12}$ Upon exposure of $\mathbf{8 c}$ to triphosgene in the presence of $\mathrm{Et}_{3} \mathrm{~N}$ followed by addition of $\mathrm{HBr},{ }^{12}$ the desired product $9 \mathrm{c}$ was obtained in low yield along with unstable brominated product 12. The acid lability of a pyrano[3,2-e]indole afforded troublesome,

Table 1 Comparison of ${ }^{1} \mathrm{H}$ and ${ }^{13} \mathrm{C}$ NMR data of synthetic compound 2 and natural fontanesine $\mathrm{B}$

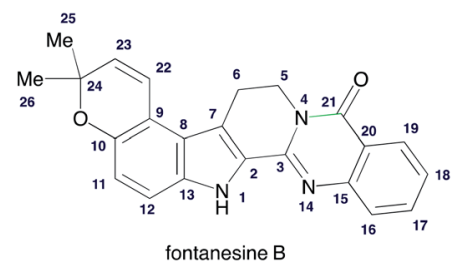

${ }^{1} \mathrm{H}$ NMR (DMSO- $d_{6}, 500 \mathrm{MHz}, \delta$ in ppm)

Natural fontanesine B

$1.40\left(6 \mathrm{H}, \mathrm{s}, \mathrm{CH}_{3}-25,26\right)$

$3.33(2 \mathrm{H}, \mathrm{t}, J=6.9 \mathrm{~Hz}, \mathrm{H}-6)$

$4.43(2 \mathrm{H}, \mathrm{t}, J=6.9 \mathrm{~Hz}, \mathrm{H}-5)$

$5.77(1 \mathrm{H}, \mathrm{d}, J=9.8 \mathrm{~Hz}, \mathrm{H}-23)$

$6.77(1 \mathrm{H}, \mathrm{d}, J=8.7 \mathrm{~Hz}, \mathrm{H}-11)$

$6.88(1 \mathrm{H}, \mathrm{d}, J=9.8 \mathrm{~Hz}, \mathrm{H}-22)$

$7.25(1 \mathrm{H}, \mathrm{d}, J=8.7 \mathrm{~Hz}, \mathrm{H}-12)$

7.47 (1H, ddd, $J=8.0,7.1,1.2 \mathrm{~Hz}, \mathrm{H}-18)$

$7.67(1 \mathrm{H}, \mathrm{dd}, J=8.3,1.2 \mathrm{~Hz}, \mathrm{H}-16)$

$7.81(1 \mathrm{H}, \mathrm{ddd}, J=8.3,7.1,1.5 \mathrm{~Hz}, \mathrm{H}-17)$

$8.16(1 \mathrm{H}, \mathrm{dd}, J=8.0,1.5 \mathrm{~Hz}, \mathrm{H}-19)$

$11.72(1 \mathrm{H}, \mathrm{s}, \mathrm{H}-1)$
Synthetic compound 2

$1.34\left(6 \mathrm{H}, \mathrm{s}, \mathrm{CH}_{3}-25,26\right)$

$3.06(2 \mathrm{H}, \mathrm{t}, J=7.5 \mathrm{~Hz}, \mathrm{H}-6)$

$4.38(2 \mathrm{H}, \mathrm{t}, J=6.9 \mathrm{~Hz}, \mathrm{H}-5)$

$5.81(1 \mathrm{H}, \mathrm{d}, J=9.8 \mathrm{~Hz}, \mathrm{H}-23)$

$6.53(1 \mathrm{H}, \mathrm{d}, J=9.7 \mathrm{~Hz}, \mathrm{H}-11)$

$6.93(1 \mathrm{H}, \mathrm{s}, \mathrm{H}-22)$

$7.12(1 \mathrm{H}, \mathrm{s}, \mathrm{H}-12)$

$7.43(1 \mathrm{H}, \mathrm{td}, J=7.4,1.2 \mathrm{~Hz}, \mathrm{H}-18)$

$7.64(1 \mathrm{H}, \mathrm{d}, J=8.1 \mathrm{~Hz}, \mathrm{H}-16)$

$7.77(1 \mathrm{H}, \mathrm{td}, J=6.5,1.2 \mathrm{~Hz}, \mathrm{H}-17)$

$8.12(1 \mathrm{H}, \mathrm{d}, J=8.0 \mathrm{~Hz}, \mathrm{H}-19)$

$11.71(1 \mathrm{H}, \mathrm{s}, \mathrm{H}-1)$

${ }^{13} \mathrm{H}$ NMR (DMSO- $d_{6}, 126 \mathrm{MHz}, \delta$ in ppm)

$112.6(\mathrm{C}-9)$

$112.7(\mathrm{C}-12)$

$115.6(\mathrm{C}-11)$

$116.5(\mathrm{C}-7)$

$119.2(\mathrm{C}-22)$

$120.6(\mathrm{C}-20)$

$120.9(\mathrm{C}-8)$

$125.9(\mathrm{C}-18)$

$126.4(\mathrm{C}-16)$

$126.5(\mathrm{C}-19)$

$127.9(\mathrm{C}-2)$

130.1 (C-23)

$134.3(\mathrm{C}-17)$

$134.4(\mathrm{C}-13)$

$145.2(\mathrm{C}-3)$

$146.2(\mathrm{C}-10)$

$147.4(\mathrm{C}-15)$

$160.5(\mathrm{C}-21)$

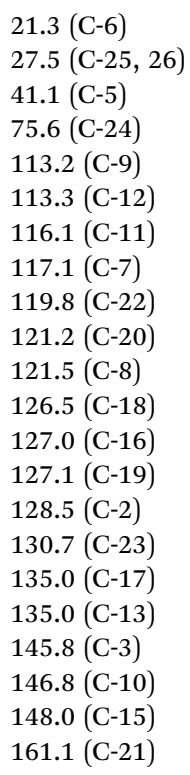


with polymerized materials being the major spot observed. As this polymerization presumably arises from activated urea intermediate 16, which was generated from less electrophilic acid chloride 14 (ref. 14 and 16b) or more electrophilic intermediate 15 by addition/elimination process by $\mathrm{HBr}$ and $\mathrm{Et}_{3} \mathrm{~N},{ }^{16}$ it was clear that the $\mathrm{Et}_{3} \mathrm{~N}^{14 b}$ and $\mathrm{HBr}$ would require to be dismissed at the cyclization step in our synthetic route.

Because the product yield was not sufficient (up to 6\% yield), further investigations were carried out. After intensive investigations, it was serendipity that we found that the treatment of 8 with triphosgene in the presence of $\mathrm{Et}_{3} \mathrm{~N}$ at room temperature afforded a trichloromethyl carbamate intermediate $13 \mathbf{b}$ in $88 \%$ yield (Scheme 4). ${ }^{17}$ Then, after aqueous work-up to remove $\mathrm{Et}_{3} \mathrm{~N}$ in the reaction media, $13 \mathrm{~b}$ was heated in DMSO to afford $9 \mathrm{~b}$ in $86 \%$ yield. Furthermore, by employing a stepwise method, we obtained $\mathbf{9}$ from 8 in good yield through the carbamoyl ion 17 (ref. 18) using a single column chromatography. To the best of our knowledge, this is the first time that an unstable trichloromethyl carbamate intermediate has been applied to the $\mathrm{C}-\mathrm{C}$ bond formations. ${ }^{\mathbf{1 1 - 1 7}} \mathrm{In}$ contrast to the mild Bischler-Napieralski-type cyclization developed by Saikawa and Nakata, ${ }^{19}$ and Clayden,${ }^{20}$ our protocol does not require additives to promote the cyclization.

Numerous attempts were made in case of benzyl-substituted lactam 9a; however, all of them led to rapid decomposition (Scheme 5). On the other hand, treatment of $9 \mathbf{b}$ with $p$-toluenesulfonic acid $(p \text {-TsOH })^{21}$ afforded the deprotected lactam 10 in $17 \%$ yield. As expected, lactam 9c could also be deprotected under the same conditions to afford 10 in $67 \%$ yield. In general, 2,4-DMB group is more easily removed than PMB group. ${ }^{21}$

With the synthetic access to 9, we were set to answer whether 9 could be deprotected keeping the alkene, pyran, and indole intact. Finally, the condensation of 10 and anthranilic acid (11a) in the presence of $\mathrm{POCl}_{3}$ (ref. 22) generated the final product 2 (Scheme 6), whose structure was determined by spectroscopic experiments. All the physical data of synthetic 2 were in good agreement with those reported for the natural product (Table 1). ${ }^{1}$

In conclusion, we have successfully accomplished the total synthesis of fontanesine B using C4 Pictet-Spengler/allylic transposition as the key step to construct the pyrano[3,2-e]indole core using the transient directing group (TDG). In this cyclization, the TDG played the dual important role of directing group and reagent. ${ }^{23}$ In addition, the unprecedented carbamate intermediate produced in the carbonylative cyclization could be converted into pyrano[3,2-e]pyrido[3,4-b]indoles only by heating through the Bischler-Napieralski-type cyclization. Further investigations including application of the $\mathrm{C} 2$ and $\mathrm{C} 4$ cyclization strategy ${ }^{24}$ to the syntheses of other indole alkaloids is ongoing in our laboratory.

\section{Conflicts of interest}

There are no conflicts to declare.

\section{Acknowledgements}

This work was financially supported by JSPS (KAKENHI Grant Number $16 \mathrm{~K} 18849$ for T. A.) as a Grant-in-Aid for Young Scientists (B).

\section{Notes and references}

1 R. S. Cabral, P.-M. Allard, L. Marcourt, M. C. M. Young, E. F. Queiroz and J.-L. Wolfender, J. Nat. Prod., 2016, 79, 2270 .

2 (a) J. E. Macor, C. B. Fox, C. J. Johnson, B. K. Koe, L. A. Lebel and S. H. Zorn, J. Med. Chem., 1992, 35, 3625; (b) J. E. Macor, K. Ryan and M. E. Newman, Tetrahedron, 1992, 48, 1039; (c) J. E. Macor, D. H. Blank and R. J. Post, Tetrahedron Lett., 1994, 35, 45; (d) J. E. Macor, Tetrahedron Lett., 1995, 36, 7019; (e) J. E. Macor, O. D. Langer, J. Z. Gougoutas, M. F. Malley and L. A. M. Cornelius, Tetrahedron Lett., 2000, 41, 3541.

3 J. P. M. Plung, G.-J. Koomen and U. K. Pandit, Tetrahedron Lett., 1992, 33, 2179.

4 J. A. May, H.-H. Chen, A. Rusinko, V. M. Lynch, N. A. Sharif and M. A. McLaughlin, J. Med. Chem., 2003, 46, 4188.

5 M. S. Sinicropi, A. Caruso, F. Conforti, M. Marrelli, H. EI Kashef, J.-C. Lancelot, S. Rault, G. A. Statti and F. Menichini, J. Enzyme Inhib. Med. Chem., 2009, 24, 1148.

6 In alkaloids synthesis, pyran formation had been conducted at a late stage. For reviews, see: (a) H.-J. Knölker and K. R. Reddy, Chem. Rev., 2002, 112, 3193; (b) M. Ishikura, K. Yamada and T. Abe, Nat. Prod. Rep., 2010, 27, 1630; (c) A. W. Schmidt, K. R. Reddy and H.-J. Knölker, Chem. Rev., 2012, 102, 4303; (d) M. Ishikura, T. Abe, T. Choshi and S. Hibino, Nat. Prod. Rep., 2013, 30, 694; (e) M. Ishikura, T. Abe, T. Choshi and S. Hibino, Nat. Prod. Rep., 2015, 32, 1389.

7 (a) T. Abe, T. Ikeda, R. Yanada and M. Ishikura, Org. Lett., 2011, 13, 3356; (b) T. Abe, T. Ikeda, R. Yanada and M. Ishikura, Org. Lett., 2013, 15, 3622; (c) T. Abe, T. Itoh, S. Hibino, T. Choshi and M. Ishikura, Tetrahedron Lett., 2014, 55, 5268; (d) T. Itoh, T. Abe, S. Nakamura and M. Ishikura, Heterocycles, 2015, 91, 1423; (e) T. Itoh, T. Abe, T. Choshi, T. Nishiyama and M. Ishikura, Heterocycles, 2016, 92, 1132; $(f)$ T. Abe and K. Yamada, Org. Lett., 2016, 18, 6504; (g) T. Abe, K. Kida and K. Yamada, Chem. Commun., 2017, 53, 4362; (h) T. Itoh, T. Abe, T. Choshi, T. Nishiyama and M. Ishikura, Heterocycles, 2017, 95, 507; ( $i$ ) T. Abe, T. Suzuki, M. Anada, S. Matsunaga and K. Yamada, Org. Lett., 2017, 19, 4275; (j) T. Abe and K. Yamada, Org. Lett., 2018, 20, 1469; ( $k$ ) T. Abe and M. Terasaki, Helv. Chim. Acta, 2018, 101, e1700284; (l) T. Abe, Heterocycles, 2018, 96, 490.

8 (a) K. Yamada, Y. Namerikawa, T. Abe and M. Ishikura, Heterocycles, 2009, 77, 825; (b) K. Yamada, Y. Namerikawa, T. Haruyama, Y. Miwa, R. Yanada and M. Ishikura, Eur. J. Org. Chem., 2009, 5752.

9 (a) T. Abe and K. Yamada, J. Nat. Prod., 2017, 80, 241; (b) T. Abe, T. Haruyama and K. Yamada, Synthesis, 2017, 49, 4141.

10 K. Yamada, S. Yamaguchi, N. Hatae, T. Abe, T. Iwamura and M. Ishikura, Heterocycles, 2011, 83, 815.

11 Phosgene cyclization of $\mathrm{N}$-substituted tryptamines has not been reported. For examples of phosgene cyclization of primary tryptamines via isocyanates, see: (a) F. Bracher and D. Hilderband, Liebigs Ann. Chem., 1992, 1315; (b) 
K. C. Nicolaou, J. L. Kiappes, W. Tian, V. B. Gondi and J. Becker, Org. Lett., 2011, 13, 3924; (c) J. Zhang, S. Da, X. Feng, X. Chen, J. Jiang and Y. Li, Chin. J. Chem., 2013, 31, 123.

12 For examples of triphosgene mediated halogenations, see:

(a) C. E. Ayala, A. Villalpando, A. L. Nguyen, G. T. McCandless and R. Kartika, Org. Lett., 2012, 14, 3676; (b) A. Villalpando, C. E. Ayala, C. B. Watson and R. Kartika, J. Org. Chem., 2013, 78, 3989; (c) M. A. Sapotra, L. Ngo and R. Kartika, J. Org. Chem., 2015, 80, 8815; (d) A. Villalpando, M. A. Sapotra, T. H. Tugwell and R. Kartika, Chem. Commun., 2015, 51, 15075; (e) A. H. Cleveland, F. R. Fronczek and R. Kartika, J. Org. Chem., 2018, 83, 3367. 13 For selected examples of coupling reactions using triphosgene, see: (a) A. Armstrong, I. D. Edmonds and M. E. Swarbrick, Tetrahedron Lett., 2003, 44, 5335; (b) O. P. Gulin, F. Rabanal and E. Giralt, Org. Lett., 2006, 8, 5385; (c) W. Su, S. J. Gray, R. Dondi and G. A. Burley, Org. Lett., 2009, 11, 3910; (d) S. T. Le Quement, T. Flagstad, R. J. T. Mikkelsen, M. R. Hansen, M. C. Givskov and T. E. Nielsen, Org. Lett., 2012, 14, 640; (e) Z. Wu, T. Hu, L. He and B. Gong, Org. Lett., 2012, 14, 2504; (f) L. Fang, G. Yao, Z. Pan, C. Wu, H.-S. Wang, G. A. Burley and W. Su, Org. Lett., 2015, 17, 158; (g) K. Leczycka-Wilk, K. Dabrowa, P. Cmoch and S. Jarosz, Org. Lett., 2017, 19, 4596; $(h)$ S. E. Varjosaari, P. Suating and M. J. Adler, Synthesis, 2016, 48, 43.

14 For reviews, see: (a) L. Cotarca, P. Delogu, A. Nardelli and V. Sunjic, Synthesis, 1995, 553; (b) L. Cotarca, T. Geller and J. Répási, Org. Process Res. Dev., 2017, 21, 1439.

15 (a) J. Bermudez, S. Dabbs, K. A. Joiner and F. D. King, J. Med. Chem., 1990, 33, 1929; (b) P. A. Barsanti, Y. Xia, W. Wang, K. G. Mendenhall, L. M. Langniton, S. Ramurthy, M. C. Phillips, S. Subramanian, R. Boyce, N. M. Brammeier, R. Constantine, D. Duhl, A. O. Walter, T. J. Abrams and P. A. Renhowe, US Pat. Appl. US 20070037853, CAN 146:251846, 2007.
16 (a) L. Contarca and H. Eckert, Phosgenations - A Handbook, WILEY-VCH Verlag GmbH \& Co. KGaA, Weinheim, Germany, 2003; (b) L. Pasquato, G. Modena, L. Cotarca, P. Delouge and S. Mantovani, J. Org. Chem., 2000, 65, 8224; (c) V. K. Gumaste and A. R. A. S. Deshmukh, Tetrahedron Lett., 2004, 45, 6571.

17 Trichloromethyl carbamate easily decomposes to give the corresponding carbamic acid, see: A. C. Sosa, R. Conway, R. T. Williamson, J. P. Suchy, W. Edwards and T. Cleary, Org. Process Res. Dev., 2011, 15, 1458.

18 S. Hwang, D. Kim and S. Kim, Chem.-Eur. J., 2012, 18, 9977. 19 For the pioneering examples of Bischler-Napieralski-type cyclization using isopropyl carbamates and $\mathrm{P}_{2} \mathrm{O}_{5}$, see: $(a)$ S. Adachi, K. Watanabe, Y. Iwata, S. Kameda, Y. Miyaoka, M. Onozuka, R. Mitsui, Y. Saikawa and M. Nakata, Angew. Chem., Int. Ed., 2013, 52, 2087; (b) S. Adachi, M. Onozuka, Y. Yoshida, M. Ide, Y. Saikawa and M. Nakata, Org. Lett., 2014, 16, 358.

20 For an example of a mild Bishler-Napieralski-style cyclization using $\mathrm{KI}$ as a promoter, see: M. M. Amer, A. C. Carrasco, D. J. Leonard, J. W. Ward and J. Clayden, Org. Lett., 2018, 20, 7977.

21 C.-Y. Chern, Y.-P. Huang and W. M. Kan, Tetrahedron Lett., 2003, 44, 1039.

22 M. Decker, Eur. J. Med. Chem., 2005, 40, 305.

23 During the preparation of this manuscript, Zeng and $\mathrm{Li}$ reported a two-in-one strategy using a transient directing group (TDG) for palladium-catalyzed functionalization. See: H. Zheng, Z. Wang and C.-J. Li, Angew. Chem., Int. Ed., 2019, 58, 2859.

24 To the best of our knowledge, the synthetic approach involving both Pictet-Spengler and Bischler-Napieralski cyclization has not been explored. For reviews, see: (a) J. Stöckigt, A. P. Antonchick, F. Wu and H. Waldman, Angew. Chem., Int. Ed., 2011, 50, 8538; (b) M. Chrzanowska, A. Grajewska and M. D. Rozwadowska, Chem. Rev., 2016, 116, 12369. 